\title{
Redox Equilibria of Tin Ions in Alkali Borate Melts
}

\author{
Hiroshi YAMASHITA, Shinya SHIMAOKA and Takashi MAEKAWA \\ Department of Applied Chemistry, Faculty of Engineering, Ehime University, 3, Bunkyo-cho, Matsuyama-shi 790-8577
}

\author{
アルカリホウ酸塩融体中のスズイオンの酸化還元平衡 \\ 山下 浩·島岡慎也・前川 尚 \\ 愛媛大学工学部応用化学科, 790-8577 松山市文京町 3
}

\begin{abstract}
The $\mathrm{Sn}^{4+}-\mathrm{Sn}^{2+}$ equilibrium in binary sodium borate melts was studied by means of differential pulse voltammetry. The half-wave potentials in the reduction of $\mathrm{Sn}^{4+}$ to $\mathrm{Sn}^{2+}$ shift to the negative with an increase in $\mathrm{Na}_{2} \mathrm{O}$ content and a decrease in temperature. These results indicate that the population of $\mathrm{Sn}^{4+}$ increases with an increase in basicity. A linear relation between $\log r\left(r=\left[\mathrm{Sn}^{2+}\right] /\left[\mathrm{Sn}^{4+}\right]\right)$ and optical basicities was observed. $\log r$ was also found to depend linearly on thermodynamic basicity, such as $-\log a\left(\mathrm{Na}_{2} \mathrm{O}\right)$ where $a\left(\mathrm{Na}_{2} \mathrm{O}\right)$ denotes the activity of $\mathrm{Na}_{2} \mathrm{O}$ in melts.

[Received October 3, 1997; Accepted March 30, 1998]
\end{abstract}

Key-words : $\left[\mathrm{Sn}^{2+}\right] /\left[\mathrm{Sn}^{4+}\right]$ ratio, Pulse voltammetry, Half-wave potential, Basicity, Glass melts

1. Introduction

Oxidation-reduction equilibria of multivalent metal ions in glass melts depend on the temperature and duration of the melting procedure, the melt composition and the ambient oxygen pressure. Recent investigations of refining agents and the redox equilibria of refining ions, especially in relation to the temperature dependence of the concentration ratio of redox pair ions, are issues of great importance for the glass industry. Among them, tin is also used as float bath in the float method. It is important to know the redox equilibria of tin in glass melts. Electrochemical methods have been successfully applied to the redox equilibria in glass melts. ${ }^{1)-10)}$ In particular, Rüssel et al. measured the half-wave potentials of reductions for various ions by square-wave voltammetry. ${ }^{7)-9)}$ We also have examined the half-wave potential of $\mathrm{Cr},{ }^{4)} \mathrm{Sb}^{5)}$ and $\mathrm{Fe}^{6)}$ ions in borate and silicate melts and explained these redox equilibria in terms of the basicities of the melts. The determination of the redox ratio $r\left(r=\left[\mathrm{Sn}^{2+}\right] /\left[\mathrm{Sn}^{4+}\right]\right)$, and examination of the coordination structures around tin ions are also important issues. In this latest study, we have measured the half-wave potentials for the reduction of $\mathrm{Sn}^{4+}$ in binary alkali borate melts by differential pulse voltammetry.

\section{Electrode reaction}

The voltammetry uses three electrodes; i.e., a reference, a working and a counter electrode, in which current (i)potential $(E)$ curves are recorded during electrolysis. ${ }^{2), 10)}$ The reference and working electrode potentials correspond to the following reaction:

$(1 / 2) \mathrm{O}_{2}+2 \mathrm{e}=\mathrm{O}^{2-}$ (reference electrode)

Generally, two reduction peaks are observed in $i-E$ curves. Rüssel also observed these two step reactions in an earlier investigation.8) These two reductions at the working electrode can be written as:

$$
\begin{aligned}
& \mathrm{Sn}^{4+}+2 \mathrm{e}=\mathrm{Sn}^{2+}(\text { first step }) \\
& \mathrm{Sn}^{2+}+2 \mathrm{e}=\mathrm{Sn}^{0}(\text { second step })
\end{aligned}
$$

The present experiment was limited within the first-step reaction, so that the overall reaction is given by:

$$
\mathrm{Sn}^{4+}+\mathrm{O}^{2-}=\mathrm{Sn}^{2+}+(1 / 2) \mathrm{O}_{2}
$$

The voltage, $E$, the difference between the working and reference electrode potentials is related to the formal potential, $E^{0^{\prime}}$, under $1.013 \times 10^{5} \mathrm{~Pa}$ of oxygen as given by:

$$
\begin{aligned}
E=E^{0^{\prime}} & -(R T / 2 F) \ln r \\
& -(R T / 2 F) \ln D\left(\mathrm{Sn}^{2+}\right) / D\left(\mathrm{Sn}^{4+}\right)
\end{aligned}
$$

diffusion coefficient, respectively. When gas-liquid equilibrium was attained and the diffusion coefficient of $\mathrm{Sn}^{4+}$ is the same as that of $\mathrm{Sn}^{2+}$, the formal potential in $\mathrm{Eq}$. (5) can be replaced by the half-wave potential, $E_{1 / 2}$, which can be expressed in terms of the following equation:

$$
E_{1 / 2} \fallingdotseq(R T / 2 F) \ln r
$$

\section{Experimental}

One mol\% samples of $\mathrm{SnO}$ or $\mathrm{SnO}_{2}$ were melted in a platinum crucible with desired quantities of boric acid and alkali carbonate at $1273 \mathrm{~K}$ in a pretreatment furnace. SnO was used only in the determination of the time required to attain the constant peak potential. After measurements were taken, several melts were quenched to form glasses and offered for chemical analyses. The concentrations of sodium ions were determined by flame spectrophotometry. The tin-ion content was determined by atomic absorption.

The cell assembly was the same as that shown in a previous paper ${ }^{5)}$ with the oxygen gas introduced at the bottom of the reaction tube. The potential was scanned at a rate of $10 \mathrm{mV} / \mathrm{s}$. The height and duration of a pulse were set at $10 \mathrm{mV}$ and $50 \mathrm{~ms}$, respectively, and the time between

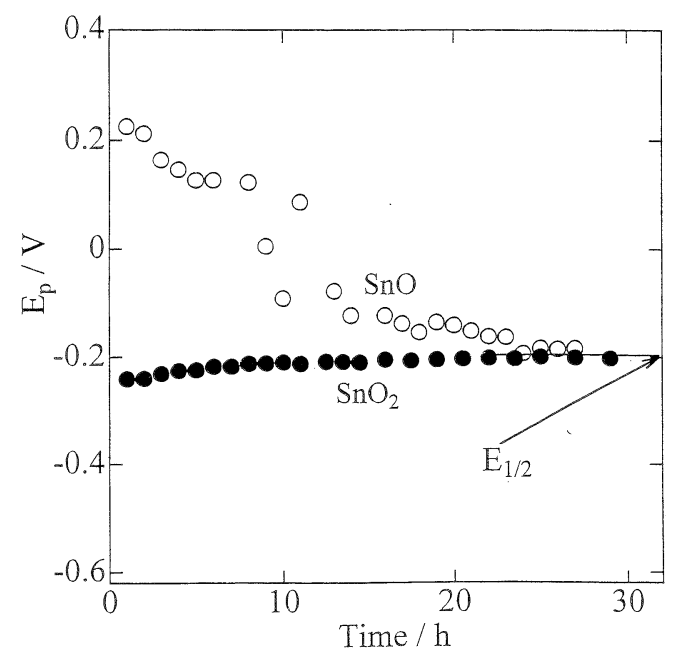

Fig. 1. Relation between the peak potential and duration of heat treatment in $25 \mathrm{Na}_{2} \mathrm{O} \cdot 75 \mathrm{~B}_{2} \mathrm{O}_{3}$ melt at $1163 \mathrm{~K}$.

(○) from $\mathrm{SnO},(\mathbf{O})$ from $\mathrm{SnO}_{2}$. 
pulses at $100 \mathrm{~ms}$. In a preliminary experiment, the time required for the determination of the half-wave potential was examined. Figure 1 represents the time lapse to attain the constant potentials in a $25 \mathrm{Na}_{2} \mathrm{O} \cdot 75 \mathrm{~B}_{2} \mathrm{O}_{3}$ melt. After about $24 \mathrm{~h}$ the two initial values from the reduced $(\mathrm{SnO})$ and oxidized $\left(\mathrm{SnO}_{2}\right)$ sides coincided, so that the half-wave potential was only determined after $24 \mathrm{~h}$ had elapsed from when the cell assembly was inserted into the furnace.

\section{Results and discussion}

The analytical compositions of two freely selected glasses determined by the three measurement procedures for each sample were $28.9 \mathrm{Na}_{2} \mathrm{O} \cdot 71.1 \mathrm{~B}_{2} \mathrm{O}_{3}\left(30 \mathrm{Na}_{2} \mathrm{O} \cdot 70 \mathrm{~B}_{2} \mathrm{O}_{3}\right)$ and $19.1 \mathrm{Na}_{2} \mathrm{O} \cdot 80.9 \mathrm{~B}_{2} \mathrm{O}_{3}\left(20 \mathrm{Na}_{2} \mathrm{O} \cdot 80 \mathrm{~B}_{2} \mathrm{O}_{3}\right)$. The numerical values in parentheses are the batch's composition. The loss of alkali oxide seems to increase with an increase in the initial content. However, it was not that large as to preclude the composition of the melts being represented by batch composition. The total loss of tin-ion content was $2.6 \%$ on average among the four glasses. Moreover, the total tin-ion concentration did not change during experiments.

The temperature dependence of the half-wave potential is shown in Fig. 2. The half-wave potentials at $1230 \mathrm{~K}$ are also plotted in Fig. 3 as a function of sodium-oxide content. As can be seen from this figure, the half-wave potentials shift toward the negative with an increase in $\mathrm{Na}_{2} \mathrm{O}$ content and with a decrease in temperature. $\log r$ derived from Eq. (6) is shown as a function of temperature in Fig. 4. Pyare and Nath. determined $r$ in alkali silicate glasses by the chemical analysis of quenched glasses whose melts equilibrated at $1673 \mathrm{~K}$ in air. They showed $r$ decreased with an increase in basicity. ${ }^{11)}$ The $r$ of glasses can be examined in terms of the complex formation of $\mathrm{Sn}^{4+}$ and $\mathrm{Sn}^{2+}$ ions. Through the application of Mössbauer spectroscopy, Dannheim and Frey, and Paul et al. determined the coordination numbers of $\mathrm{Sn}^{2+}$ and $\mathrm{Sn}^{4+}{ }^{42), 13)} \mathrm{Sn}^{4+}$ ions were found to have a strong tendency to form complex ions by coordinating with free oxide ions $\left(\mathrm{O}^{2-}\right)$ accompanying alkali ions especially in basic melts. Six-coordinated $\mathrm{Sn}^{4+}$ ions were also observed in acidic melts, while four-coordinated $\mathrm{Sn}^{2+}$ ions were observed in basic melts. Thus the following two reactions are thought to occur:

$$
\begin{aligned}
& \mathrm{Sn}^{4+}+n \mathrm{O}^{2-}=\mathrm{SnO}_{n}^{-(2 n-4)} \\
& \mathrm{Sn}^{2+}+m \mathrm{O}^{2-}=\mathrm{SnO}_{m}^{-(2 m-2)}
\end{aligned}
$$

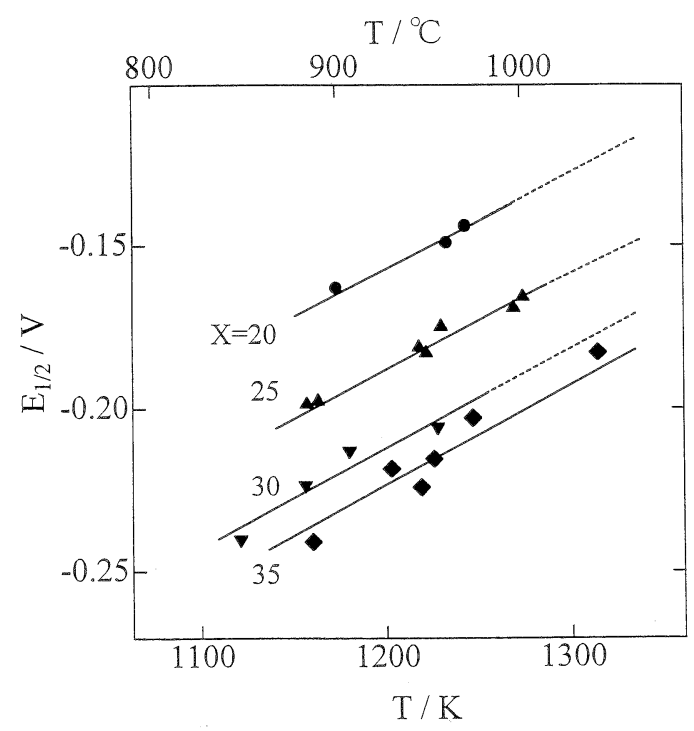

Fig. 2. Temperature dependence of the half-wave potential in $X$ $\mathrm{Na}_{2} \mathrm{O} \cdot(100-X) \mathrm{B}_{2} \mathrm{O}_{3}$ melts.

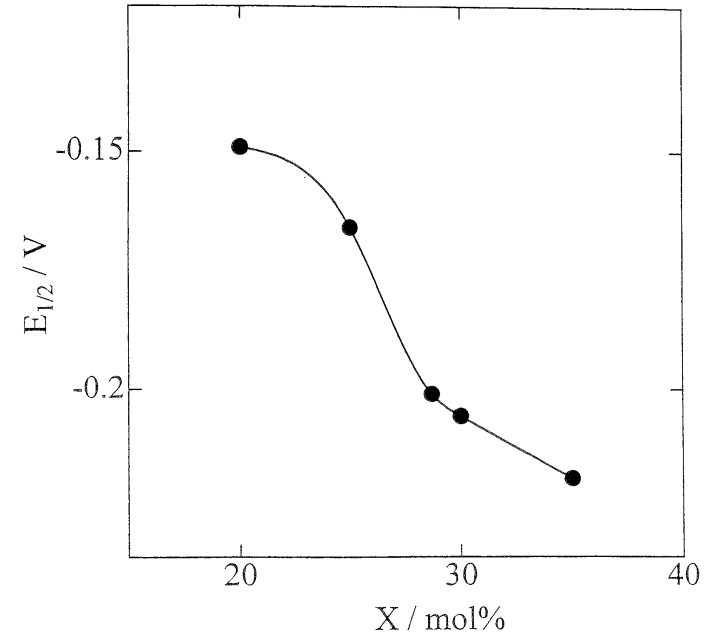

Fig. 3. Relation between the half-wave potential and melt composition in $X \mathrm{Na}_{2} \mathrm{O} \cdot(100-X) \mathrm{B}_{2} \mathrm{O}_{3}$ melts at $1230 \mathrm{~K}$.

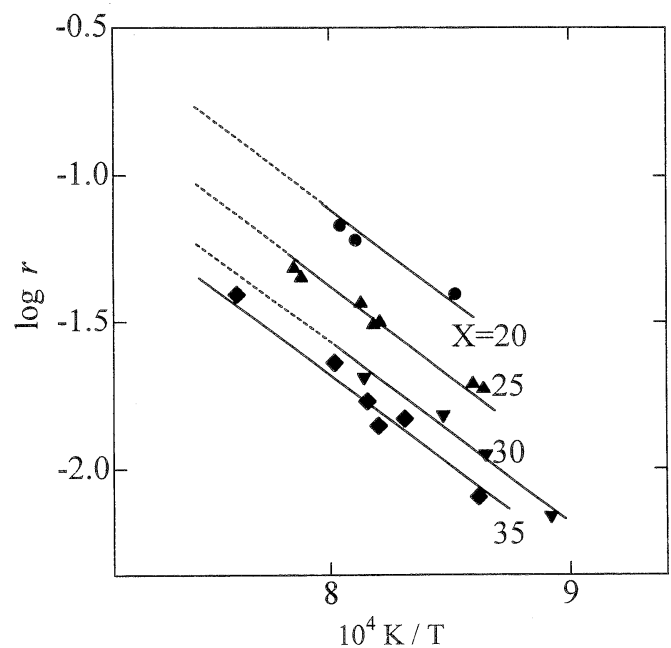

Fig. 4. Effect of melt composition and temperature on the $\left[\mathrm{Sn}^{2+}\right] /\left[\mathrm{Sn}^{4+}\right]$ concentration ratio $(r)$ in $X \mathrm{Na}_{2} \mathrm{O} \cdot(100-X) \mathrm{B}_{2} \mathrm{O}_{3}$ melts.

Thus, $r_{\text {theor }}$ is expressed as the following equation: ${ }^{10), 14}$

$$
\begin{aligned}
\gamma_{\text {theor }}= & {\left[\mathrm{Sn}^{2+}\right]_{\text {total }} /\left[\mathrm{Sn}^{4+}\right]_{\text {total }} } \\
= & \left(\left[\mathrm{Sn}^{2+}\right]_{\text {free }}+\left[\mathrm{Sn}^{2+}\right]_{\text {complex }}\right) /\left(\left[\mathrm{Sn}^{4+}\right]_{\text {free }}\right. \\
& \left.+\left[\mathrm{Sn}^{4+}\right]_{\text {complex }}\right) \\
= & K_{1}\left[\mathrm{O}^{2-}\right]\left(1+K_{3}\left[\mathrm{O}^{2-}\right]^{m}\right) /\left(1+K_{2}\left[\mathrm{O}^{2-}\right]^{n}\right)
\end{aligned}
$$

$K_{1}$ is the equilibrium constant of Eq. (5). $K_{2}$ and $K_{3}$ are equilibrium constants of Eqs. (7) and (8), respectively.

If $K_{2}$ and $K_{3}$ are large enough, $\log \gamma_{\text {theor }}$ can be written as:

$\log r_{\text {theor }}=$ const. $-(n-m-1) \log \left[\mathrm{O}^{2-}\right]$

When $n-m$ is greater than $1, r_{\text {theor }}$ decreases with an increase in the concentration of $\left[\mathrm{O}^{2-}\right]$, i.e., one of the scales of basicity.

Baucke and Duffy derived a linear relation between $r$ and the theoretical optical basicity. ${ }^{15)}$ Figure 5 (a) represents a relation between $\log r$ and optical basicities. The $r$ at 1300 $\mathrm{K}$ was derived by the extrapolation of the data presented in this paper. Analogous to silicate glasses, a linear relation was also obtained in borate melts. However, a direct comparison between borate melts and silicate glasses cannot be substantiated at this stage. Tilquin et al. have proposed that chemical changes during the cooling or dissolution of the glass for chemical analysis in aqueous media should also be 


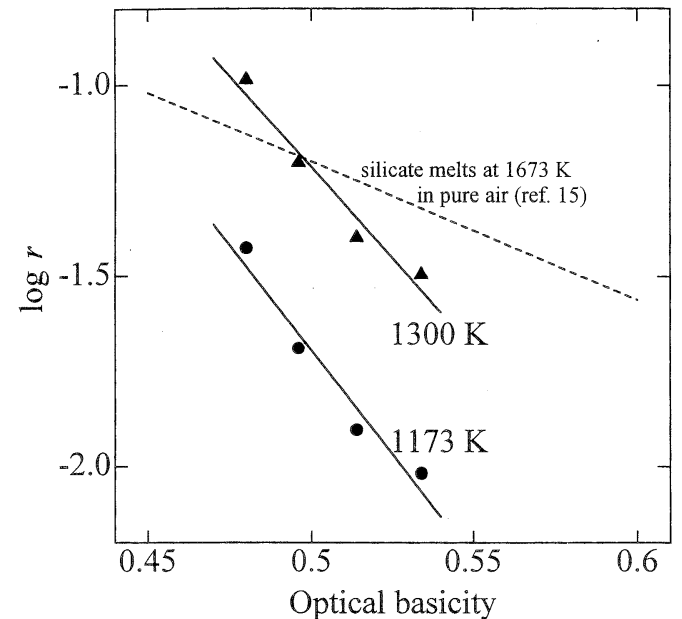

(a)

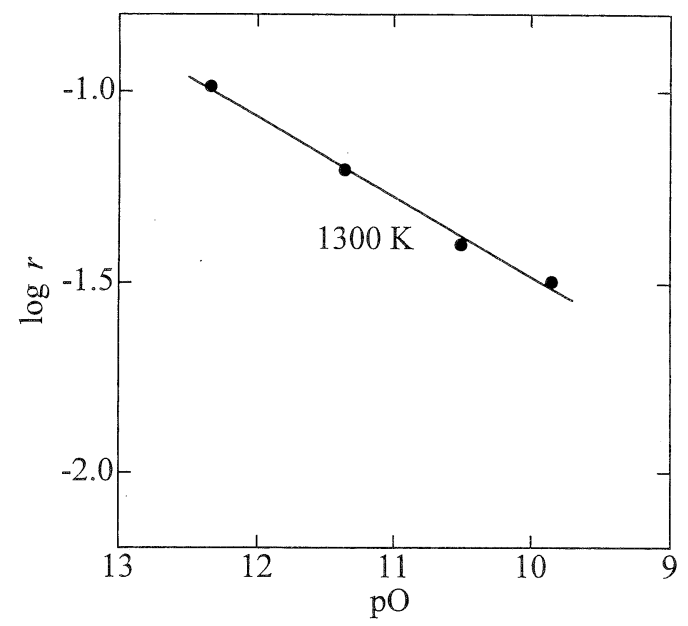

(b)

Fig. 5. (a) Relation between $\log r$ and optical basicity. (b) Relation between $\log r$ and $p \mathrm{O}$ values at $1300 \mathrm{~K}$.

considered. ${ }^{10)}$ The equilibrium constants, $K_{1}$ and $K_{2}$, depend not only on the temperature but also on the difference in the alkali ions as well as the nature of the network of oxides forming. While $n-m$, and therefore $r$, largely depends on the temperature, Denzumi et al. have proposed a new relation between the half-wave potential and the thermodynamic basicity, i.e., $p \mathrm{O}=-\log a\left(\mathrm{Na}_{2} \mathrm{O}\right)$, where $a\left(\mathrm{Na}_{2} \mathrm{O}\right)$ is the activity of $\mathrm{Na}_{2} \mathrm{O}$ in melts. ${ }^{16)}$ Figure $5(\mathrm{~b})$ represents the relation between $\log r$ and $p \mathrm{O}$ values at $1300 \mathrm{~K}^{2)}$ In this case, a linear relation was also obtained. $p \mathrm{O}$ in melts is an acceptable parameter for determining the redox equilibria in melts rather than optical basicity, which is in principle independent of temperature.

\section{Conclusion}

The half-wave potential in the reduction of $\mathrm{Sn}^{4+}$ to $\mathrm{Sn}^{2+}$ in $\mathrm{Na}_{2} \mathrm{O}-\mathrm{B}_{2} \mathrm{O}_{3}$ melts was examined by means of differential pulse voltammetry at various temperatures. The half-wave potential was observed to shift to the negative with an increase in $\mathrm{Na}_{2} \mathrm{O}$ content and a decrease in temperature. These results indicate that the population of $\mathrm{Sn}^{4+}$ increases with an increase in basicity. A linear relation between log $r\left(r=\left[\mathrm{Sn}^{2+}\right] /\left[\mathrm{Sn}^{4+}\right]\right)$ and optical basicities was observed. Moreover, $\log r$ could be expressed by thermodynamic basicity, such as $p \mathrm{O}=-\log a\left(\mathrm{Na}_{2} \mathrm{O}\right)$, where $a\left(\mathrm{Na}_{2} \mathrm{O}\right)$ represents the activity of $\mathrm{Na}_{2} \mathrm{O}$ in the melts.

Acknowledgment The authors gratefully acknowledge the financial assistance given by the Glass Process Forum for the present investigation.

\section{References}

1) A. Sasahira and T. Yokokawa, Electrochim. Acta, 30, 441-48 (1985).

2) T. Yokokawa, K. Kawamura and S. Denzumi, Trends in Electrochem., 1, 71-89 (1992).

3) K. Takahashi and Y. Miura, J. Non-Cryst. Solids, 80, 11-19 (1986).

4) T. Morita, H. Yamashita and T. Maekawa, J. Ceram. Soc. Japan, 102, 419-23 (1994).

5) M. Yokozeki, T. Moriyasu, H. Yamashita and T. Maekawa, J. Non-Cryst. Solids, 202, 241-47 (1996).

6) M. Nakashima, H. Yamashita and T. Maekawa, J. Non-Cryst. Solids, 223, 133-40 (1998).

7) C. Montel, C. Rüssel and E. Freude, Glastech. Ber., 61, 59-63 (1988).

8) C. Rüssel, J. Non-Cryst. Solids, 119, 303-09 (1990).

9) C. Rüssel, Glastech. Ber., 66, 93-99 (1993).

10) J.-Y. Tilquin, P. Duveiller, J. Gilbert and P. Claes, J. NonCryst. Solids, 211, 95-104 (1997).

11) R. Pyare and P. Nath, J. Am. Ceram. Soc., 65, 549-54 (1982).

12) H. Dannheim and T. Frey, "Borate Glasses," Ed. by L. D. Pye, V. D. Frechette and N. J. Kreidl, Plenum Press, New York (1977) pp. 227-38.

13) A. Paul, J. D. Donaldson, M. T. Donoghue and M. J. K. Thomas, Phys. Chem. Glasses, 18, 125-27 (1977).

14) H. Hirashima, T. Yoshida and R. Brückner, Glastech. Ber., 61, 283-92 (1988)

15) F. G. K. Baucke and J. A. Duffy, Phys. Chem. Glasses, 34 158-63 (1993).

16) S. Denzumi, T. Yamada, K. Kawamura and T. Yokokawa, Mater. Trans., JIM, 35, 591-95 (1994). 